Please refer to the published version when citing:

Gössling, S. \& Cohen, S. (2014). Why sustainable transport policies will fail:

EU climate policy in the light of transport taboos. Journal of Transport Geography, 39, 197-

207, DOI: 10.1016/j.jtrangeo.2014.07.010

**A summary news article on this paper, intended to reach a broader audience, has been

published in The Conversation: https://theconversation.com/political-taboos-leave-politiciansunwilling-to-take-steps-to-cut-transport-emissions-30537

\title{
Why sustainable transport policies will fail: \\ EU climate policy in the light of transport taboos
}

\section{Stefan Gössling}

Lund University, Sweden

Linnaeus University, Sweden

\section{Scott Cohen}

University of Surrey, UK

\begin{abstract}
There is widespread consensus that current climate policy for passenger transportation is insufficient to achieve significant emission reductions in line with global climate stabilization goals. This article consequently has a starting point in the notion of 'path dependency' (Schwanen, Banister and Anable 2011) and an observed 'implementation gap' (Banister and Hickman 2012), suggesting that significant mitigation policies for transport do not emerge in the European Union because of various interlinked 'transport taboos', i.e. barriers to the design, acceptance and implementation of such transport policies that remain unaddressed as they constitute political risk. The paper argues that without addressing transport taboos, such as highly unequal individual contributions to transport volumes and emissions, social inequality of planned market-based measures, the role of lobbyism, and the various social and
\end{abstract}


psychological functions of mobility, it will remain difficult to achieve significant emission reductions in passenger transport. Yet, transport taboos remain largely ignored among EU policy makers because their discussion would violate 'order', i.e. harm specific interests within neoliberal governance structures and the societal foundations and structures of transport systems built on these.

Key words: automobility, aviation, climate change, European Union, mobility consumption, policy, passenger transport

\section{Introduction}

Transport in the EU27 has grown considerably over the past decade. In the period 1995-2010, average annual growth in passenger transport was $1.3 \%$, totalling 6,424 trillion passenger kilometres (pkm) in 2010, or an average of 12,869 km travelled per person per year (EC 2012). Notably, this figure does not include air and sea transport outside the EU27 and is a considerable underestimate of overall transport distances covered by EU citizens (e.g. Åkerman [2012] for Sweden). Transport accounts for $31.7 \%$ of final energy consumption in the EU 27, out of this $82.1 \%$ as a result of road transport and $13.6 \%$ as a result of intra-EU air transport. This corresponds to $29.9 \%$ of $\mathrm{CO}_{2}$ emissions in the $\mathrm{EU}$ in 2009 (EC 2012). Transport emissions increased by $36 \%$ in the period 1990-2007, while emissions from all other sectors decreased by $15 \%$ in the same period (EC 2011).

Further growth in transport volumes and associated emissions is likely. Globally, the International Energy Agency (IEA 2012) anticipates a doubling of the number of passenger cars between 2011-2035. Aviation industry projections foresee global traffic volume growth (revenue passenger kilometres) in the order of $4.7 \%$ (Airbus 2012) to 5.0\% (Boeing 2012) per year, leading to a tripling of air travel between 2005-2050 (IEA 2009, see also Owens et al. 2010). This will considerably increase transport's share in emissions, even in economies where overall transport volumes continue to grow at a more moderate rate. Clearly, such developments will make it difficult for the transport sector to stay within the limits of global climate policy objectives (e.g. Chèze et al. 2013).

The EU has implemented two legislative instruments to reach its climate mitigation targets. The first is a trade scheme (the EU Emission Trading Scheme, ETS), imposing caps on $\mathrm{CO}_{2}$ 
emissions of large emitters (Directive 2009/29/EC). The second is legislation assigning targets for non-emissions trading sectors on a national level, covering transport, residential, services and some industry (Decision 406/2009/EC). Regarding the latter, emission reductions are to be achieved through various mechanisms, including, in urban areas, a phasing out of vehicles with internal combustion engines (ICEs), smaller road passenger vehicles, higher shares of collective transport, and urban mobility and infrastructure designs that facilitate walking and cycling (EC 2011). Overall, the EC (2011) suggests that emissions from transport will decline, compared to 2008 , by $60 \%$ by 2050 , with an interim goal of $-20 \%$ by 2030 . The EC outlines, however, that “curbing mobility is not an option" (EC 2011: 5), thereby putting legislation objectives and measures somewhat at odds with opinion that to achieve absolute emission reductions, energyintense forms of mobility will have to decline (Anable et al., 2012; Banister, 2008, 2011; Chapman, 2007; Daly and Ó Gallachóir, 2011; Dubois et al. 2011, IEA 2012, UNWTO-UNEPWMO 2008).

To achieve emission reductions in transport in the EU, a wide range of market-based, command-and-control and soft policy measures are theoretically available (e.g. Friman et al. 2012; OECD and UNEP, 2011; Sterner, 2007). However, while there is ample research on the effects of specific measures within these three categories, there exists, in the words of Banister and Hickman (2013: 292), a major 'implementation gap', defined as the way in which scientific knowledge is translated into policies. Various explanations have been provided for the existence of such a gap, including a societal and political focus on ecological modernization and neoliberal governance, i.e. belief systems comprising elements of technological innovation, (limited) market-based measures, and (voluntary) behavioural change, ultimately resulting in 'path dependency' and social lock-in, i.e. a situation where (in)actions of the past condition future outcomes (Hall, 2013; Schwanen et al., 2011 ).

This paper takes a similar, yet different viewpoint, based on the observation that a series of aspects with key relevance for passenger transport volume growth appear to remain largely ignored in the EU policy agenda. The paper thus confirms Banister and Hickman's (2012) notion that available policy measures are not implemented because of various barriers (May, 2013; Stough and Rietveld, 1997; Rietveld and Stough, 2005), though developing an alternative concept for explanation, which we term 'transport taboos'. 'Taboo' is a word derived from the Polynesian 'tabu', denoting any sort of prohibition, i.e. something that is 'forbidden' (RadcliffeBrown, 1939). An important sub-context is that someone who does touch an object that is tabu 
becomes tabu her/himself, with consequences: "he [sic] is regarded as being in a state of danger, and this is generally stated by saying that if he fails to observe the customary precautions he will be ill and perhaps die" (ibid: 6). Taboos are consequently "issues banned as constituting a risk" (Merriam-Webster, 2013: no page), and refer in the context of this paper to the political risk of touching upon any of the issues outlined in the following sections: To touch a taboo constitutes a violation of norms, and implies a danger for the transgressor to become marginalised and to 'die' politically.

Anthropological research on taboos confirms that these are dangerous (Radcliffe-Brown, 1939; Douglas, 1966). This is because taboos represent 'order', and thus touching a taboo will create disorder, constituting a violation of norms and values: "the ideal order of society is guarded by dangers which threaten transgressors" (Douglas, 1996: 3). As Tetlock (2003) underlines, social or individual commitments to certain values are absolute, as these are sacred, and hence inviolable. Taboos are interlinked with sacred values, and thus represent issues that are virtually impossible to address, as this demands infringing on values closely linked to belief systems (cosmologies) and identities, causing cognitive dissonance as a result of disruption. When a taboo is actually violated, this will result in conflict with a given order, and result in 'moral outrage' (Tetlock et al., 2000), i.e. affective and behavioural reactions including "anger, contempt, and even disgust toward violators; and enthusiastic support for both norm enforcement (punishing violators) and metanorm enforcement (punishing those who shirk the burdensome chore of punishing deviants)" (ibid: 855).

Transport taboos are thus issues that constitute fundamental, yet ignored cognitive and affective barriers to the implementation of significant climate policy in transportation. Taboos are different from barriers of implementation, because they exist on a fundamentally different level than structural, economic, technical or behavioural barriers: they cannot be addressed politically without considerable danger to the integrity of the norm violator, either among peers - which can be powerful individuals or organizations -, or the broader public or community.

Like the Polynesian origin of the word tabu, taboos, and more specifically transport taboos, are explicitly geographical in nature. The degree to which an issue is taboo, or even not taboo at all, is contextually dependent. Indeed, the transport taboos presented in this paper are situated in place, with the political risk they constitute uneven, and varying across regions and nationstates. The geographical focus of this paper falls on those issues that may be seen as most taboo 
in EU climate policy, but examples also tease out national differences, highlighting pockets of both extreme resistance to particularly taboo issues in transport policy, and also where possible to places wherein the same types of issues have met less political resistance and been at least partially overcome through more sustainable transport solutions.

As an example of a notable transport taboo at the national scale, a paradox in German transport policy is that the country, one of the major proponents of far-reaching EU climate policy, maintains its 'no speed limits' policy, even though the importance of such limits for climate mitigation is well documented (Asensio et al., 2014; Hill et al., 2012). Moreover, various opinion polls in Germany have indicated broad public support in favour of speed limits (e.g. ARD, 2013; BUND, 2007; Süddeutsche Zeitung, 2010). Yet, none of the political parties have been willing to raise a discussion of this taboo issue, which would likely lead to moral outrage by car associations and producers, who are powerful agents in German public discourse on car driving. As an example of a situation where a transport taboo was actually addressed, i.e. the very low price for fuel in Germany at the end of the 1990s, this had considerable negative consequences for the 'transgressor', the Green party. Demanding that a litre of fuel cost 5 German marks (US\$2.80) before the election in 1998, the party lost $0.6 \%$ of votes, declining from $7.3 \%$ in 1994 to $6.7 \%$ in 1998 (Bundeswahlleiter 2013). Notably, the opposition expressed moral outrage at the proposition, and voiced contempt in their answering election campaign “Lass dich nicht anzapfen” (“don’t let yourself be tapped”).

Transport taboos exist, it is argued, because they constitute a risk to political decision makers, in the sense that their consideration would require transcending neoliberal forms of governance to initiate fundamental sociocultural change - in other words, a process creating disorder. The purpose of this paper is thus twofold. It introduces the concept of transport taboos as a new dimension to be considered in the discussion of progress in mobility governance, and underlines the need to more fully analyse transport taboos. At the same time, the paper emphasises the need to confront and overcome taboos, with the ultimate goal to provide a platform for a renewed discussion of the failure of policymakers to adequately address transport climate mitigation policy. Clearly, not all stakeholders will ignore all taboos, and not all taboos will be equally relevant to achieve stated policy goals. Hence, the subsequent introduction of the concept of transport taboos is a starting point for further debate: it is acknowledged that various knowledge gaps remain, and that empirical work is needed to confirm and identify taboos. Future research on taboos would allow to better address and, ultimately, overcome these. 
Based on primarily sociological perspectives - as well as insights derived from science \& technology studies and transport geography - the following sections introduce and discuss a non-exhaustive list of transport taboos that may be considered key obstacles to the successful implementation of significant climate mitigation policy in transportation. Focus is placed on the two most relevant transport modes from an emissions perspective, i.e. cars and aviation. 'Taboos' were identified on the basis of the authors' personal observations and their interdisciplinary review of the secondary literature. That material has been structured and summarized into 10 interrelated and interdependent categories of transport taboos in the EU that are discussed sequentially but not in order of importance (see table 1 for a summary list of the taboos and their brief explanations). It needs to be noted that the list of transport taboos as presented in this article is subjective, and not exhaustive with regard to the number of issues identified or the choice of references selected to justify each of the aspects. Case studies to substantiate the taboos are not systematically employed and empirical research is needed to confirm taboos. Case studies are also drawn mainly from across the EU to help illustrate the issues being discussed on an ad hoc basis: exceptions in a few countries to the examples presented are highlighted. The list of transport taboos discussed in this paper is likely to be incomplete; the purpose of this paper is to provide evidence for the existence of various taboos; to fully explore each of these taboos in greater analytical depth is beyond its scope.

Table 1 Summary of EU transport taboos and brief explanations

\begin{tabular}{|l|l|}
\hline \multicolumn{1}{|c|}{ Transport taboo } & \multicolumn{1}{c|}{ Brief explanation } \\
\hline Transport mitigation strategies lack credibility & $\begin{array}{l}\text { Mitigation in transportation lacks a credible } \\
\text { basis in terms of a clearly defined and monitored } \\
\text { emissions target. Industry and policy makers put } \\
\text { emphasis on technological solutions yet to be } \\
\text { developed. Technological optimism is not } \\
\text { matched by transport scenarios. }\end{array}$ \\
\hline $\begin{array}{l}\text { The contribution to transport volumes is highly } \\
\text { skewed }\end{array}$ & $\begin{array}{l}\text { Rather than participation in auto- and aero- } \\
\text { mobility being equally distributed in society, a } \\
\text { minor share of highly mobile travellers, mostly } \\
\text { from higher income classes, are responsible for a } \\
\text { significant share of the overall distances } \\
\text { travelled, as well as emissions associated with } \\
\text { this transport. The issue is particular acute in the } \\
\text { context of aeromobility. }\end{array}$ \\
\hline $\begin{array}{l}\text { Highly mobile and environmentally aware } \\
\text { travellers will not reduce their mobility }\end{array}$ & $\begin{array}{l}\text { Highly mobile travellers, including the most } \\
\text { environmentally aware, are unwilling to change } \\
\text { their mobility patterns, such as by flying less. }\end{array}$ \\
\hline
\end{tabular}




\begin{tabular}{|l|l|}
\hline $\begin{array}{l}\text { A large share of transport is unrelated to } \\
\text { specific transport needs }\end{array}$ & $\begin{array}{l}\text { Much transport demand is induced through low } \\
\text { prices and/or status-related incentives. Not } \\
\text { fulfilling physical transport needs, these kinds of } \\
\text { trips are arguably dispensable. }\end{array}$ \\
\hline $\begin{array}{l}\text { Market-based measures will effect in particular } \\
\text { the less wealthy }\end{array}$ & $\begin{array}{l}\text { There are social inequalities in the affectedness } \\
\text { of market-based policy measures due to } \\
\text { differences in income levels, with low-income } \\
\text { groups to be disproportionally affected. The } \\
\text { mobile elite will be not be affected enough to } \\
\text { change behaviours. }\end{array}$ \\
\hline $\begin{array}{l}\text { Energy-intense transport is the least taxed and } \\
\text { the most subsidized }\end{array}$ & $\begin{array}{l}\text { Market distortions exist wherein aviation, and to } \\
\text { a lesser extent cars, remain over-subsidized. The } \\
\text { costs of the most harmful transport modes are } \\
\text { thus externalized. }\end{array}$ \\
\hline $\begin{array}{l}\text { Lobbyism influences and waters down transport } \\
\text { policy }\end{array}$ & $\begin{array}{l}\text { There is considerable influence of automobile } \\
\text { and aviation organizations on the design of } \\
\text { policies. The sectors protect themselves through } \\
\text { linking mobility to fundamental human rights. }\end{array}$ \\
\hline $\begin{array}{l}\text { Key issues in climatically sustainable transport } \\
\text { systems remain ignored }\end{array}$ & $\begin{array}{l}\text { Despite wide recognition of the importance of } \\
\text { several measures for mitigating car emissions, } \\
\text { such as reducing speed limits and implementing } \\
\text { congestion charges, such important issues are } \\
\text { typically overlooked. }\end{array}$ \\
\hline $\begin{array}{l}\text { Emerging societal structures are ignored } \\
\text { Mechanisms fostering high mobility patterns are } \\
\text { embedded in socio-cultural norms, with habits } \\
\text { of consumption difficult to change due to their } \\
\text { entanglement with identities and affective } \\
\text { dimensions. }\end{array}$ \\
\hline $\begin{array}{l}\text { Scenarios projecting transport volume growth do } \\
\text { not account for changes in family structures and } \\
\text { the stretching of social relations, which } \\
\text { increasingly requires bouts of movement for the } \\
\text { maintenance of social networks. }\end{array}$ \\
\hline
\end{tabular}

\section{Transport mitigation strategies lack credibility}

As outlined, transport accounts for $29.9 \%$ of $\mathrm{CO}_{2}$ emissions in the EU (in 2009; EC 2012). Yet, even though significant continued growth in transport volumes is expected (figure $1 \mathrm{a}, \mathrm{b}$ ), indicating vast discrepancies between emission reduction objectives and business-as-usual developments, there is no evidence of a political acknowledgement of the sector's growth in contradicting mitigation objectives, and no systematic assessment of the effectiveness of various policy measures to reduce emissions. "Roadmaps" for the EU27 as presented in figure 
1b appear to anticipate particularly steep emission reductions after 2030, though it remains unclear whether such scenarios are probable. Hill et al. (2012: xiii) summarize that there is: "a need to stimulate a broad range of technical and non-technical options", "a need for a wide range of complementary policy instruments", and, overall, "an urgent need for action". This supports the notion that, currently, there is no effective integrated mix of market-based, command-and-control and soft policy measures for mitigation in transport in the EU27, nor specific, monitored year-on-year reduction goals.
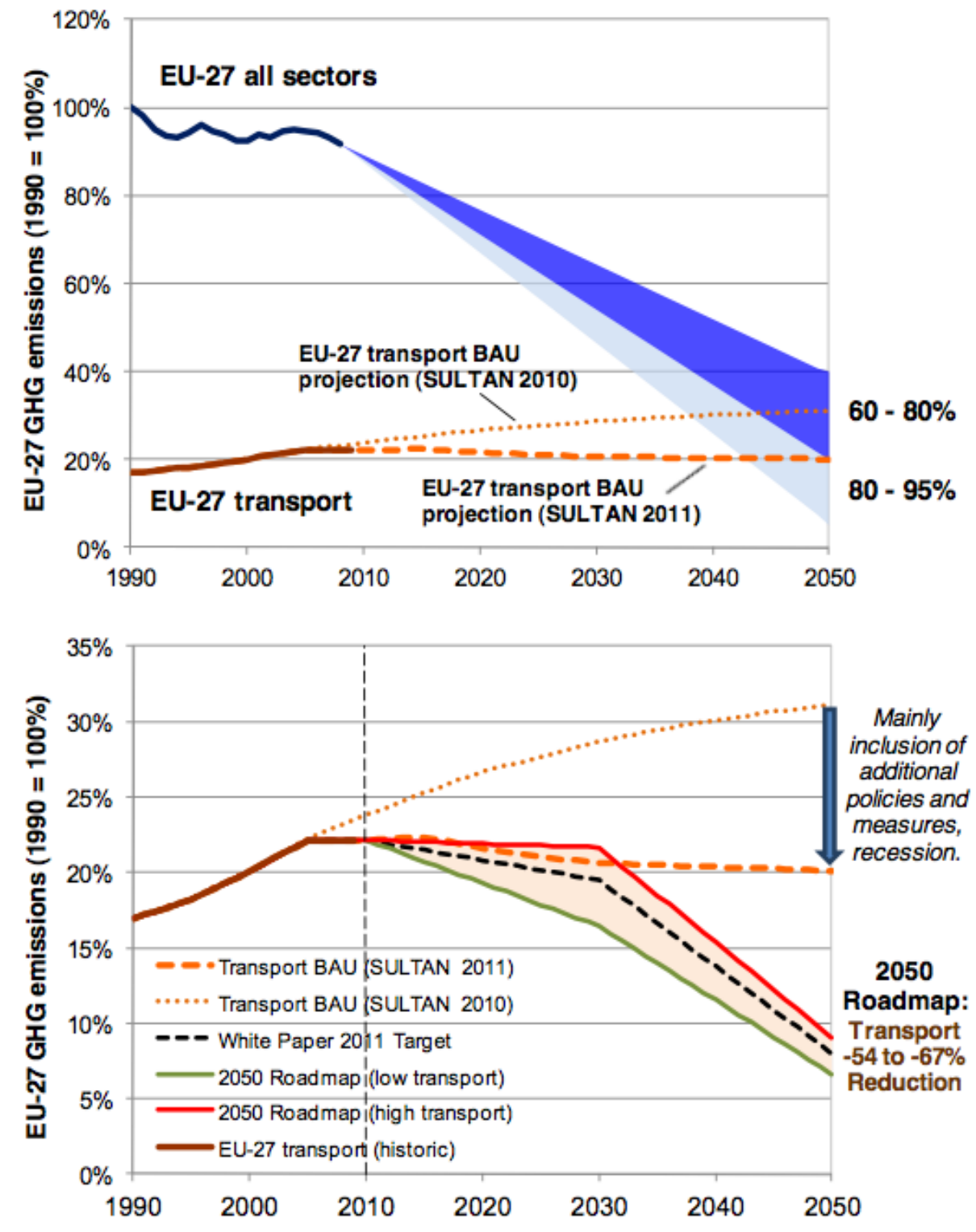

Figure 1a, b: EU overall emissions trajectories against transport emissions

Source: Hill et al. 2012

Country specific assessments of options to reduce emissions from transport come to similar conclusions. For instance, Daly and Ó Gallachóir (2011) suggest that car emissions in Ireland 
in 2020 will be $2 \%$ above those of 2005 , while a reduction of $20 \%$ is required across all nonETS sectors. An important aspect of the Ireland model is that considerable rebound effects are included, while these appear to have been ignored in other EU scenarios (e.g. Dray et al. 2012; Hill et al. 2012). Consequently, technological innovation alone is unlikely to achieve climate targets, even though it is acknowledged that national policies may exist that consider a variety of policy interventions.

The mismatch is particularly evident in aviation, where the International Air Transport Association (IATA) has presented a vision of "carbon neutral growth" achievable in the "medium term" future (IATA, 2009). In its "four-pillar strategy", the organization outlines timelines, acknowledging that the technology that will be necessary to achieve these goals is unknown, and referring to "revolutionary engine architectures" to be implemented after 2020. In comparison, the International Energy Agency (IEA, 2009) has highlighted that technical capacity to reduce the energy intensity of new aircraft is equivalent to $0.6 \%-1.0 \%$ per year on average and that the annual historical rate of improvement in load factors (approximately $0.2 \%$ per year) could reach close to its upper limit by 2025 . The reliance on biofuel as a technological solution remains problematic because of uncertainties over full life-cycle emissions and landuse requirements that put energy and food crops in conflict (Stratton et al. 2010; UNEP, 2009; Vera-Morales and Schäfer 2009). Overall, it is obvious that industry puts great emphasis on technological solutions yet to be developed, while policy makers also put emphasis on technological progress (e.g. EC 2011). This technological optimism is not matched by transport scenarios, which indicate a significant gap between emission pathways and mitigation objectives (e.g. Anable et al. 2012; Dubois et al. 2011; Dray et al. 2012; IEA, 2012; UNWTOUNEP-WMO, 2008). Even though it is obvious that there is a gap and no plausible strategy to close it, this remains largely undebated in political circles, as closing this gap would require fundamental changes in the neoliberal structures of transport provision that facilitate mobility growth, e.g. 'powering down' (Urry, 2013).

\section{The contribution to transport volumes is highly skewed}

There is a common belief that corporeal mobility is global, involving populations in developed and developing countries. For instance, car media suggest that the global number of cars now exceeds 1 billion (Ward's Auto, 2011), while IATA reports that airlines carried 2.8 billion passengers in 2011 (IATA, 2013). Such figures foster an understanding that auto- and aeromobility involve most of the world population. This ignores that there are huge differences 
in the power geometries of individual mobility (e.g. Gössling et al. 2009, Schäfer et al. 2009), with a minor share of highly mobile travellers being responsible for a significant share of the overall distances travelled, as well as emissions associated with this transport. For instance, with regard to automobility, it has been shown that Swedish men with incomes over $€ 27,800$ per year use three times as much energy for car travel than men earning $€ 9,300-13,900$ per year, while men in the highest income category were also shown to drive $13 \%$ more than women in the same income category (Carlsson-Kanyama and Lindén, 1999).

Differences are far greater in aeromobility. In the UK, $61 \%$ of overall personal (non-business) transport emissions are produced by just $20 \%$ of the population, with air travel over comparably long distances being the dominant contributor (Brand and Preston, 2010). A survey of the French population's leisure travel patterns revealed that $5 \%$ of the population account for an estimated $50 \%$ of the distances travelled (Gössling et al. 2009). Likewise, a survey among Swedish air travellers found individuals reporting up to 300 return flights per year, with the 11 most frequent flyers (3.8\% of the sample) accounting for $28 \%$ of all flights made (ibid). In a survey of leisure travellers in Zanzibar, Tanzania, the 10 most frequent flyers had covered an average 180,000 pkm each in $2002 \& 2003$ (two years; air travel only), with a maximum of 24 countries visited by one traveller in this period (Gössling et al. 2006). The mobility of some more privileged individuals may be frequent and long-distance, substantiating Cohen et al.'s (2011) notion of 'binge flying'. This also needs to be seen in the light of the fact that most people's aeromobility is extremely limited. Peeters et al. (2007a) estimate that taking into account multiple international flights made by the same individuals, a share as large as $97-98 \%$ of the world's population does not participate in international air travel in a given year.

There is also a notable regional distribution in transport volumes, with almost one third of all air travel, measured in trip numbers, taking place in the USA (Bureau of Transportation Statistics, 2008, IATA 2008). This will shift, however, as rapidly expanding middle classes in countries such as China, India and Indonesia fuel aero-expansion (see e.g. Voigt 2011 for Indonesia). Finally, there is a relationship between flight length and emissions, with the longest flights (top 20\%) accounting for about $78 \%$ of emissions from aviation (Peeters et al. 2007b). Again, evidence suggests that it is mostly men in the higher income classes consuming aeromobility, with for instance one Swedish survey finding that all of the most highly mobile travellers (>100 flights per year) fell into the highest $>€ 100,000$ annual net income group (Gössling and Nilsson, 2010). 
Overall, these results suggest that a comparably small share of the world population contributes a comparably large share to transport volumes, and an even greater share of transport energy use and emissions, due to the use of more energy intense transport modes among the highly mobile. For a rough estimate, a highly mobile person flying 100,000 pkm per year in business class will generate $25 \mathrm{t} \mathrm{CO}_{2}$ (at $0.250 \mathrm{~kg} \mathrm{CO}_{2}$ per pkm, i.e. twice the amount of emissions in economy class). This amount will rise considerably if private aircraft are involved. In comparison, average per capita emissions from all transport in the EU27 are in the order of $2 \mathrm{t}$ $\mathrm{CO}_{2}$ per year $\left(13,000 \mathrm{pkm}\right.$, mixed transport, at $0.15 \mathrm{~kg} \mathrm{CO}_{2}$ per $\left.\mathrm{pkm}\right)$.

Flying, as well as frequent driving with powerful cars is largely a domain of the wealthy, with clear relationships between income and mobility consumption (Casey, 2010, Schäfer et al. 2009). Consequently, it is in particular the economic, political and cultural elites, those who also tend to be more politically powerful, who are contributing most to global emissions of greenhouse gases, and also using the most energy intense transport modes such as private jets or first class flights (Gössling et al. 2009). Paradoxically, an emerging class of 'sustainability elites' may exacerbate the problem: Holden and Linnerud (2011) found that individuals in Norway with pro-environmental transport attitudes travel more by plane for leisure than those without. In summary, evidence suggests considerable inequalities in individual contributions to emissions that remain taboo in political discussions, particularly with regard to aviation, even though there is considerable evidence that without addressing the mobility patterns of the highly mobile, who are often themselves influential in policymaking, it will be difficult to achieve overall reductions in emissions from transport. The distribution of aeromobility remains poorly understood globally, and further empirical work is needed, perhaps in cooperation with airlines, to better understand inequalities in mobility consumption.

\section{Highly mobile \& environmentally aware travellers will not reduce their mobility}

As outlined, without changes in the mobility patterns of the most mobile, it becomes even less likely to achieve significant emission reductions. Yet, there is considerable evidence that mobility elites are unlikely to change their transport patterns. Anecdotal evidence suggests, for instance, that politicians have been provided with frequent flyer status by airlines, and that they can use bonus miles acquired on the job for private use (news.at, 2013; see also Gössling and Nilsson, 2010). Politicians are also provided with company car privileges, while the voluntary choice of a service bicycle or free use of public transport is fraught with difficulties 
(Süddeutsche Zeitung, 2011). More systematic surveys of attitudes of the highly mobile to change travel patterns suggest that there exists a limited willingness to travel less, or with reduced privileges (Cohen and Higham, 2011; Kroesen, 2012; Mair, 2011; Scott et al. 2012). Even the most environmentally aware - and often also most active - travellers appear unwilling to willing to change travel behaviour (Barr et al. 2010; Cohen et al., 2013; Gössling et al. 2009; McKercher et al. 2010). The UK Sustainable Consumption Roundtable (2006: 35) concluded that flying less is not imaginable: "consumers struggle with the idea of flying less. They candidly acknowledge that the prospect of cutting back on flights is extremely unattractive" (see also Randles and Mander 2009; Hares et al., 2010). The situation is more complex for car driving, where better options exist to switch modes (see Anable, 2005; Schwanen and Lucas 2011). In conclusion, there is considerable resistance by in particular the most mobile to change mobility patterns, even though further empirical research is needed to better understand these interrelationships.

\section{A large share of transport is unrelated to specific transport needs}

There is a general notion that all transport is necessary, as communicated by airlines and car lobby organizations. For instance, airlines and air travel organizations have for years used images of interpersonal reunions to show that flying is an important means of social connectivity. Likewise, the importance of aviation for conducting business has been taken up in countless campaigns. IATA's web-campaign (January 2013) states that "Nearly 3 billion people fly annually for business and pleasure. Flying connects" as well as that " $3.5 \%$ of the global economy relies on aviation. Aviation supports business". In the light of aviation's contribution to climate change (e.g. Douglas et al. 2011), ethical questions regarding the various purposes of travel may be raised. Though it may be difficult to assign normalizing values to specific motivations for travel as well as destination choices, there are differences between, for instance, driving to work and participating in scenic drives, a visit to see family and a stag weekend away, and a longer-term annual holiday and a short-term long-haul "breakneck break" (Mills, 2008: no page). These offer opportunities for research into the ethics of greenhouse gas emissions associated with transportation.

There is also evidence that mobility can be induced, or fulfil purposes other than transport needs. For instance, Nilsson (2009) suggests that as much as $60 \%$ of Low-Cost-Carrier (LCC) demand may be stimulated, in the sense that there is no specific motivation for travel, other than the fact that a destination is offered at a very low price. Similar mechanisms may be at 
work when airlines offer 'All You Can Fly Passes' (e.g. Wideroe, 2013), or when airlines offer flights based on a very low rate as a sales argument, without even indicating the destination (e.g. Ryanair's 2014 marketing campaign). Evidence also suggests that frequent flyers engage in additional flights to maintain their traveller status (Gössling and Nilsson, 2010) and that frequent flying is related to status and social identity, i.e. reasons other than physical transport needs (Hibbert et al. 2013a, b). As noted by CNN (2010), as many as 50,000 members of the organization FlyerTalk may go on 'mileage runs' towards the end of the year to retain or attain elite airline status. Given the energy-intensity of flying first class compared to economy class, there is also an issue of individual comfort at the expense of disproportional individual contributions to climate change. Travel journalists and the media are known to promote longhaul destinations because of 'freebies' provided by these destinations, or a general need to 'fill space' in newspapers and magazines, creating and sustaining notions of ideal or 'must-see' destinations (e.g. Bright and Matsuura, 2009). Group deal-of-the-day websites, such as 'Groupon Getaways', further induce demand by heavily reducing package holidays bundled with air travel; with a short purchase window and by showing how many others have bought the package that day, such institutions produce perceptions of scarcity and a 'bandwagon' effect amongst consumers. Very limited research appears to have been conducted on these issues.

Regarding automobility, the size and power of cars is often unrelated to transport needs, and many trips may not be necessary (e.g. scenic drives, driving and flying for sport). Overall, a considerable share of trips by both car and aircraft is consequently made for reasons with varying degrees of urgency or necessity. While it is difficult to assess whether status- motivated travel necessary for personal wellbeing (Kroesen and Handy, 2014) can be weighed against the loss of livelihoods due to climate change in developing countries, the lack of a political discussion of these interrelationships, and unwillingness to openly question more 'flippant' transport decisions at the risk of being seen as against mobility freedoms, indicates a taboo deserving further study.

\section{Market-based measures will effect in particular the less wealthy}

Most measures to reduce emissions in transport are market-based. Regarding aviation, the EU has sought to integrate the sector in an open ETS, which remains the only regional policy approach for the aviation sector worldwide. According to the European Commission, inclusion of aviation in the ETS would achieve reductions of $183 \mathrm{Mt} \mathrm{CO}_{2}$, or the equivalent of a $46 \%$ 
reduction compared to a business-as-usual scenario. However, as the Commission points out, the option of purchasing credits from within the EU ETS means that the sector will continue to grow, and emission reductions will be achieved in other sectors, where costs are lower (Ares, 2012).

The European Commission (EC, 2006) produced four different scenarios looking at EU ETS prices of $€ 15$ and $€ 6$ per $\mathrm{CO}_{2}$, and including or excluding international credits. These translated to cost increases in the price of a typical return flight within the EU in 2020 by between $€ 1.8$ and $€ 9$. Analyses of the implications of costs increases under various ETS or climate policy scenarios all conclude that those currently planned will not significantly change travel flows (Pentelow and Scott, 2010, 2011) or reduce absolute emissions from the aviation sector (Ares, 2012; Jotzo, 2010; Mayor and Tol, 2009; Scott et al. 2010). In the light of low costs of purchasing emission allowances, the EU ETS is thus unlikely to have any de facto importance for airlines and growth in aeromobility, while flights to and from non-European countries are not included at least until 2020 (EC 2014). Vice versa, various forms of subsidies exist, which make flying cheaper in proportion to mobility levels (see following taboo).

With regard to automobility, various mechanisms have been identified that reduce the burden of market-based measures on the wealthy and more mobile. First of all, about $50 \%$ of all new passenger car sales in the EU are company cars, which are often used by employees for both for business and personal travel (cf. Copenhagen Economics 2009). Where companies pay for cars and fuel use, this provides personal incentives to buy larger cars and to drive more. The EC (2011) has also recognized that vehicle taxation is not only linked to environmental performance, but as well to value, cylinder capacity, engine power and weight, noting that (EC 2011: 120): “... the majority of the Member States has introduced car taxes, during the last years, which are differentiated on the basis of the $\mathrm{CO}_{2}$ performance of individual passenger cars." While this introduces taxation proportional to emissions, it does not consider the role of income inequalities. SUVs, for instance, may roughly use twice as much fuel per $\mathrm{km}$ as a small car, but these are also more likely be driven by people with several times the average income. As an example, the top $10 \%$ of earners in Germany earn $41 \%$ of the gross market income (in 2003; Bach et al. 2009; see also Credit Suisse 2013). Proportionally seen, fuel taxes might thus be more burdensome for low-income groups driving smaller cars. 
The overall question is thus whether $\mathrm{CO}_{2}$ permit prices or fuel taxes will lead to price increases convincing consumers, and in particular the 'high-energy hypermobiles', to drive less or to shift to other vehicles or transport modes. Similar inequalities also exist with regard to measures seeking to punish traffic violations such as speeding, as penalties are identical for all income groups. Overall, market-based measures neither consider individual contributions to transportrelated emissions, nor the importance of income/wealth inequalities in affecting transport behaviour. This taboo, which has similar political risks to increasing income tax rates in higher tax bands, whereby asking the wealthy to carry a larger share is invariably contested, is also of relevance with regard to existing and future subsidies (e.g. Winchester et al. 2013). Further research into these inequalities and their impact on mobilities is consequently required.

\section{Energy-intense transport is the least taxed and the most subsidized}

It is generally recognized that there exist considerable market distortions with regard to train, bus, car and air travel. Most notable is that aviation, the most energy intense form of transport, is exempted from VAT on international flights - a subsidy corresponding to a revenue shortfall of $\$ 10$ billion in the EU according to Transport \& Environment (2012) -, and does not pay fuel taxes. In further contradiction of sustainable transport policy principles, scheduled and low cost carriers continue to receive direct subsidies. Ryanair alone may have received subsidies in the order of $€ 800$ million in a single year, though not even members of the EU parliament appear to know the exact amount (see e.g. a statement by a member of the EU parliament: Cramer, 2013).

The mobility patterns of air travellers are consequently subsidized, also including disproportionally high rewards for the most mobile, as in the case of frequent flyer programmes granting additional air miles to the highest status classes, options to receive air miles from credit card purchases, to use work-related air miles for private purposes, or to use air miles for status upgrades to business class, with corresponding increases in energy use. As an estimated 7-8\% of all flights are being paid for with air miles (Gössling and Nilsson, 2010; The Economist, 2005), there is a general financing mechanism for air travel of the highly mobile by the less mobile and cross-subsidizing of aviation through general consumption. German Lufthansa, for instance, reportedly had to plan for bonus programme payments of $€ 620$ million in 2010 alone (Spiegel 2012). 
The prevailing VAT exemption on international flights is furthermore proportional to the cost of air travel (T\&E 2012), i.e. those travelling more frequently, over long distances or in business/first class, are the most subsidized. Moreover, other subsidies are paid as governmental support to national airlines in times of crisis (cf. Doganis 2006), or regional airports with yearon-year negative balance sheets. This situation makes it difficult for international coach and high-speed train services to compete with aviation. For a national review on subsidies see e.g. Netherlands Environmental Assessment Agency (2011).

With regard to cars, the European Commission (2011, based on Copenhagen Economics 2009) has stated that direct tax revenue losses due to preferential taxation of company cars may approach $0.5 \%$ of EU GDP (€54 billion) in the 18 member states studied. Associated welfare losses from distortions are estimated to equal another $€ 15$ to $€ 35$ billion, while emissions associated with incentives to buy more fuel and larger cars are in the order of 21-43 $\mathrm{Mt} \mathrm{CO}_{2}$, i.e. equivalent to around 2-5\% of road transport emissions. In comparison, Becker et al. (2012) estimate that an average car in the EU27 entails costs to society in the order of $€ 1,600$ per year or $€ 0.05$ per driven $\mathrm{km}$, with $41-60 \%$ of this related to traffic accidents and $15-37 \%$ to climate change. These costs are externalised, i.e. paid for by society as a whole. A similar calculation was presented for Copenhagen, concluding that the net social cost of each km driven by car was $€ 0.50$, while the cost of a $\mathrm{km}$ cycled was $€ 0.08$, a result of health benefits and reduced pollution (City of Copenhagen 2009, 2012). Even though the costs/benefits of the different transport modes are well documented, these are not taken up politically to internalize costs of in particular aviation and cars, or to favour the expansion of cycle infrastructure in line with its economic benefits to society (for the notable exception of Copenhagen, Denmark see Gössling et al. 2014). The ignorance of transport costs in policy planning frameworks is consequently an issue that should receive greater attention.

\section{Lobbyism influences and waters down transport policy}

There is widespread evidence of lobbyists' influence on EU transport policy, for instance with regard to taxation, speed limits, alcohol limits, emission trading, congestion charges or toll roads. Key elements of campaigns to prevent legislation introducing climate mitigation include the underlining of the respective sector's benefits to society, its comparably small contribution to environmental change, relative improvements in environmental performance over the past, as well as a positive outlook on future technological solutions (Gössling and Peeters 2007; see 
also Brulle 2013). Messages can also be rhetorically linked with fundamental human rights. As an example, IATA (2012: 7) claims:

“....already our industry supports the livelihoods of 56.6 million people and USS2.2 trillion in economic activity. And governments must understand that with an enabling policy environment we could do much more. When aviation gets stronger, so does the economy".

In its current web-campaign (January 2013), the organization also suggests "Aviation will cut its net carbon emissions $50 \%$ by 2050 (compared to 2005). Flying is sustainable". Such campaigns are intended to influence public opinion as well as policy makers, and remain unchecked for facts. As an example, Scandinavian Airlines retains one of the oldest fleets in Europe, but regularly presents itself as an environmental champion. Its campaign "Can I fly with a clear environmental conscience? Yes, you can!" (SAS 2008) has for instance sought to communicate that aviation is responsible for only $2-3 \%$ of global emissions, while a national comparison revealed that air travel of Swedes corresponds to $11 \%$ of Swedish emissions (Åkerman 2012). The campaign also suggests that specific emissions per pkm will decline by $42 \%$ to 2020 , i.e. about $4 \%$ per year, which is twice the amount of industry objectives (e.g. IATA 2009), and more than four times observed historical efficiency gains (IEA 2009). Whether such propositions are likely to become reality is another question entirely, pointing at the need for emission monitoring programmes for airlines, to confirm or question industry claims.

The situation is more complex for automobility. Douglas et al. (2011) report that clusters of organizations with similar interests, such as car manufacturers, car retailers, car hire companies, garages, motoring organizations, oil companies, and road builders co-operate to prevent progress on key issues in sustainable transport, such as speed limits or emission targets. Car manufacturers spend $2.5-3.5 \%$ of their revenue on marketing, as well as funding of professional lobbyists and organizations to oppose fuel duty rises, emissions targets or speed cameras (Douglas et al. 2011). Arguments are built on 'freedom of choice' and 'fundamental human rights' (ibid), and driving a car has also been interlinked with constitutional rights; questioning such unfettered freedom to move is consequently particularly taboo. As an example of the success of such strategies, Douglas et al. (2011) describe how, in 2007, car manufacturers and related organizations successfully used a public relations campaign in German newspapers to question mandatory $\mathrm{EU} \mathrm{CO}_{2}$ emissions targets. The campaign gained the support from the German chancellor, who opposed and prevented new EU legislation on various occasions. 
Particular attention was paid to the issue when Germany delayed the EU limit on $\mathrm{CO}_{2}$ emissions from cars, at a time when it became known that the ruling party had received financial contributions from car manufacturer BMW (BBC 2013a; Die Zeit 2013).

Pro-car organizations in industrialized countries attract vast member numbers, with for instance the American Automobile Association (AAA) and Allgemeiner Deutscher Automobil-Club (ADAC) counting 53 and 17 million members respectively (AAA 2013; ADAC 2013). There is ample evidence of these organizations' influence on national transport policies through critical reporting on speed limits, alcohol limits, congestion charges or road tolls. Largely unrecognized, car organizations may also be particularly active in low- and middle-income countries, where the ability of governments and civil society to counteract campaigns is often more limited (Douglas et al. 2011). Very limited research appears to exist in the context of lobbying and its influence on transportation policy making.

\section{Key issues in climatically sustainable transport systems remain ignored}

Several measures are widely acknowledged as having significant importance for reducing transport emissions. For cars, these include speed limits, as well as congestion charges and road tolls/vignettes. Speed limits reduce emissions in various ways. First of all, reduced speeds demand lower energy input. For Germany, it has been calculated that introducing a speed limit of $120 \mathrm{~km} / \mathrm{h}$ would reduce emissions from cars by $2 \%$, corresponding to $2.2 \mathrm{Mt} \mathrm{CO}_{2}$ (UBA 2010). This calculation does not include knock-on effects. For instance, the VCD (2008) reports that the average engine power of cars in Germany has increased from $57 \mathrm{~kW}$ in 1985 to $74 \mathrm{~kW}$ in 2006 , with the share of cars capable to drive $>200 \mathrm{~km} / \mathrm{h}$ growing from $7.6 \%$ in 1995 to $19.0 \%$ in 2006. Speed limits would in turn lead to the introduction of lighter cars and more economical tyres and braking systems (EC, 2011), while engines could also be optimized in lower speed classes (UBA, 2010). Other effects include more constant transport flows and increasing competitiveness of other transport modes, such as trains (UBA, 2010; VCD, 2008). Yet, even though speed limits have been discussed in Germany for decades, with polls regularly revealing that a broad majority of the population supports a maximum speed limit of $130 \mathrm{~km} / \mathrm{h}$ (e.g. ARD, 2013; BUND, 2007; Süddeutsche Zeitung, 2010), the German chancellor announced in 2007 that she would not support a speed limit (VCD 2008).

As another example, Denmark increased speed limits on highways from 110 to $130 \mathrm{~km} / \mathrm{h}$ in 2004, which also caused a rise in traffic accidents (Hels et al. 2011). A similar situation exists 
in the Netherlands, where speed limits were raised to $130 \mathrm{~km} / \mathrm{h}$ (Rijkswaterstaat 2011), in spite of concerns voiced by the Netherlands Environmental Assessment Agency (PBL 2010). An exception to the general rule of speed increases in several European countries is Spain, where the government implemented speed limits as a measure to reduce fuel consumption after the financial crisis and as a reaction to increasing fuel prices (Asensio et al. 2014). Speed limits are of particular importance in urban areas, where comparative speeds are important in transport mode choices, and in particular the use of bicycles. Where speeds of motorized transport modes are reduced, interest in bicycling and walking appear to increase. Various other examples exist of measures contributing to significant reductions in emissions, but these are rarely implemented, even though they might gain considerable support in the population. For an example of a congestion charge policy first rejected and later demanded by a majority of residents in Stockholm, see Börjesson et al. (2012). Other measures, such as car free days, are now apparently unthinkable in the EU, indicating an issue that is taboo, and consequently requiring continued research efforts.

\section{Mobility consumption patterns represent the very fabric of contemporary societies}

Mobility patterns in the EU are also a result of cultural practices and social norms, in which technology, knowledge structures and emotions are involved (Sheller and Urry, 2006). It has thus been argued that the individual is not "...necessarily a sovereign, autonomous agent but rather the carrier and in some ways even the product of the practices in which s/he is involved" (Schwanen and Lucas, 2011: 22). Car and aircraft in particular have produced lifestyles, relations, communities, work and recreation patterns that represent socialization into specific norms and habits of mobility consumption (Frändberg, 2008; Lassen, 2006; Schwanen et al. 2012), shaping individual and national identities (Adey, 2010; Edensor, 2004). This is relevant, because mobility patterns are difficult to restructure or re-design when they permeate society. Mobility patterns also affect our social standing in society, often measured by the distance flown or driven, or time spent abroad. Mobility is a precondition for social status, demanding participation, for instance, in exchange programmes, or frequent and distant travel (Urry, 2011).

This valuing of the consumption of distance (Larsen and Guiver, 2013) is expressed in and symbolized by large, powerful or expensive cars, private aircraft, or high frequent flyer status: where mobility becomes an enabler of social status and identity, it is no longer a choice or an option, rather it is a necessity. Airlines consequently portray frequent flying as desirable, while car manufacturers promote powerful cars and automobility-centred lifestyles. Car expos are 
cultural mass events, attended by hundreds of thousands of visitors in days (e.g. IAA, 2012). Children are embedded in car cultures from early childhood (Sheller, 2004) and targeted in frequent flyer programmes (Gössling and Nilsson, 2010), only to be later on enrolled and socialized in programmes for car driving teenagers and young adults as offered by AAA (2013) and ADAC (2013). Aggressive and fast driving is institutionalized in car races (see Mabon, 2013), i.e. deeply nationalized events treating race car drivers as heroes. Fast driving or exceeding the speed limit is often understood to represent power, maleness and daringness, rather than a traffic offense (Gössling, 2013).

More generally, the car is now one of the most important items of individualized consumption. It provides status to its owner through sign-values that include speed, home, safety, sexual success, career, achievement, freedom, family or masculinity (Urry 2007). Cars also develop into highly personalized goods that systematically reduce mental and corporeal insufficiencies, including obesity (see Wen et al. 2006), while increasing the driver's capabilities and productivity. Personalized cars reduce anxieties and build more confident car owner identities and personalities, while becoming trusted, anthropomorphized partners. This has consequences for mobility consumption and interventions to change behaviour, because emotionally attached drivers are likely to drive more (e.g. Nilsson and Küller, 2000), while their psychological dependence on motorized individual mobility increases, also because of gains in self-esteem. Where cars are seen as 'partners', they need to be treated with respect, and where policy makers restrict car use, this often results in negative emotions, or cognitive dissonance (see Hibbert 2013a, 2013b), as social norms have been violated and order disrupted (Douglas, 1966). These interrelationships highlight that mobility consumption has importance beyond the functional, with strong symbolic and affective dimensions (Murtagh et al.2012; Sheller 2004) that socially construct touching these issues as taboo. Hence "measures [to reduce emissions] would have to include ... new unconventional instruments, such as bans on commercial advertising and glamorisation of high $\mathrm{CO}_{2}$ vehicles and certain types of carbon intensive travel in urban areas" (Banister et al. 2012: 468). Mechanisms of glamorization and the psychological functions of mobility thus deserve to be studied in greater detail.

\section{Emerging societal structures are ignored}

Scenarios projecting future transport volume growth are unlikely to fully incorporate changes in societal structures and motivations for travel, which to an increasing degree focus on the maintenance of social networks (Larsen et al., 2007). These now include family structures 
characterized by single households, separate housing, patchwork families, multiple (seasonal) housing, cross-cultural relationships over countries and continents, as well as global friendship and family structures, or movement for work (Beck and Beck-Gernsheim, 2014). Data for the EU shows that on average $13 \%$ of the population live alone, with higher shares in Denmark, Finland and Germany (19\%) and Sweden (24\%). Single household shares appear to grow (e.g. Statistisches Bundesamt, 2012, for Germany), and there is also an increasing share of single parents and children growing up between two households.

Air travel in particular is an important agent of change, as it shapes new perceptions of distance, space, and time, while creating new ways and rhythms of dwelling, travelling, and socializing in aeromobile time-spaces. Ultimately, this may necessitate more frequent bouts of movement (Adey et al, 2007; see also Kesselring, 2006; Larsen et al. 2007), representing a fundamental transformation in individual mobility patterns. It is unclear how growing up in 'liquidity' (sensu Bauman, 2007) will affect mobility patterns of future generations. However, as relationships, marriages, family- and friendship networks, as well as working environments become global in character for some sections of society, this involves more travel. UNWTO (2012), for instance, reports that $27 \%$ of all international tourism is focused on visiting friends and relations, health and religion, which suggests that a bulk of these mobilities are not necessarily viewed as a matter of choice. Impinging on these visiting friends and relatives mobilities, amongst other forms of non-discretionary travel, through restrictive transport governance has to date constituted a largely untouchable and insufficiently studied issue.

\section{Conclusions}

Technological innovation alone is unlikely to reduce transport emissions in line with EU and global mitigation objectives (e.g. Anable et al., 2012; Banister, 2008, 2011; Chapman, 2007; Daly and Ó Gallachóir, 2011; Dubois et al. 2011; Dray et al. 2012; Hill et al. 2012; IEA, 2013; UNWTO-UNEP-WMO, 2008). While policy makers discuss a wide range of policy measures aimed at working towards these objectives (e.g. OECD and UNEP, 2011), few are implemented. Notably, year-on-year reduction targets do not exist, and integrated models for EU wide transport to assess how various policies might interact, and with what result, have never been developed. It may thus be argued that current climate governance with regards to transport in the EU justifies continued growth in transport volumes rather than initiating longerterm change. 
This paper has argued that this situation may partially be explicable on the basis of a series of interrelated and interdependent 'transport taboos', i.e. issues that constitute cognitive and affective barriers to significant decarbonisation of transport systems, as they constitute a risk to decision makers, who would be viewed as violators of norms and values. Taboos include, first and foremost, an industry-led discourse that decarbonisation is on-going on the basis of technological innovation. This may be seen in the context of highly skewed contributions to transport volumes, with the most highly mobile transport elites being directly or indirectly involved in or even in charge of policy-making. Highly mobile travellers have also been identified as particularly reluctant to give up hypermobile lifestyles, while market-based measures may paradoxically force in particular the less mobile to change their transport behaviour.

Policy makers are also influenced by climate change contrarians, and car- and aviation lobbies, who are all engaged in considerable efforts to implement an understanding that all mobility is good, while environmental problems can be resolved largely through technology. At the same time, lobbies engage in measures to enrol large parts of the population in car lobby membership or bonus programmes, targeting specifically young adults and even children. This further deepens structures of liquidity, where mobility is normalized and viewed as necessity: To maintain social relations will require even greater mobility in the future, as friendship and kinship networks become increasingly global in character, another issue that is taboo.

This does not overlook that significant legislation has been implemented in some countries. In the UK, the cost of flying has increased considerably due to the introduction of an air passenger duty (HMRC, 2013), and the government has pledged $£ 400$ million ( $€ 465$ million) to encourage people to buy and drive new ultra-low emission vehicles (UK Government 2012). In France, a bonus-malus system has been implemented, charging buyers of less efficient and rewarding buyers of more efficient cars (D'Haultfœuille et al. 2011). In Denmark, the city of Copenhagen has initiated fundamental change to restructure the capital into an 'eco-metropolis' and 'the best bicycle city in the world' (City of Copenhagen, 2011). In Switzerland, 'via sicura' legislation targets excessive speeding, punishable by revocation of driving licences for at least two years and up to four years in jail (Bundesamt für Strassen, 2012). However, even though many of these measures are significant, they remain restricted to individual countries, notably without an objective to achieve specific emission reduction targets. Overall, they would thus, as exceptions, confirm the rule of policy failure. 
This paper suggests that there is a need to more fundamentally question policy structures and the entrapment of transport within a neoliberal growth paradigm, considering the role and importance of transport taboos, which appear to prevent a more fundamental discussion of the obstacles that have to be overcome to implement significant mitigation policies. If pathway dependencies are not broken up, there is, as outlined by Hall (2013), a risk of further social lock-in, dominated by neoliberal, technocentric, and ecological modernisation values that make policy learning and the questioning of prevailing paradigms difficult. The present controversy over airport expansion in the UK illustrates this issue well (BBC, 2013b): the sustainability agenda has recently been side-lined in favour of concern over economic growth, in itself an issue of sacred values (Tetlock 2003), and hence taboo. Such structural and social lock-in may be accompanied by what could be termed a social rebound effect in terms of dwindling public support for climatically sustainable transport policies, i.e. a reaction to political inaction. Currently, public support for mitigation policies appears to be high (Eurobarometer, 2011), but there is a risk that lack of political willpower will lead to the acceptance of climate risks as an unavoidable evil in the risk society (Beck, 2007), making behavioural change redundant.

It has been the intention of this paper to provide the basis for research into a new concept, transport taboos, and the role of such taboos in explaining the failure of mobility governance to sufficiently address climate mitigation for passenger transportation. Further research into each of the taboos presented in this paper is needed, however, to systematically assess their complexity and specific, and possibly often interrelated, roles in the observed 'implementation gap' of sustainable transport policies. As Douglas (1966) underlines, to touch a taboo creates disorder. Yet, in touching taboos there then also is potentiality to re-order, even though this may require overcoming psychological barriers both on the side of those touching taboos and those holding taboos sacred. Tetlock (2003) suggests that where 'sacred values' - in this context represented as unrestricted mobility - have to be traded against resource scarcity and climate change - represented by significantly higher prices for mobility, i.e. politically implemented, economic instruments to regulate transport systems -, such trade-offs need to be framed as 'tragic' if they are to stand a chance to be accepted. Addressing taboos is not without danger or political risk, however: "when economic necessity collides with cultural identity and moralreligious imperatives, and in the modern world such collisions are common, the resulting dissonance can be excruciating" (Tetlock, 2003: 320). Where order disintegrates, this will result 
in anger and contempt, enthusiastic support for norm and meta-norm enforcement, and the punishment of violators.

We thus conclude that overcoming taboos will be fraught with difficulty; yet, without overcoming taboos, significant sustainable transport policies on a broader scale are unlikely to emerge. More empirical research on taboos is needed to create a basis for such change. We suggest that this may involve the perspectives of policy makers on issues identified as 'taboo', as well as research focused on 'sacred' transport values and their underlying psychology. Mobility clearly has many functions and meanings that are rational only through social and clinical psychological lenses, and it will require a better understanding of these processes to address and overcome transport taboos. Besides these more fundamental research gaps, various other research topics are thinkable, including mobility consumption inequalities, and the transport psychologies of the hypermobile; transportation ethics; cost distribution and the impact of market-based measures; the role and impact of transport lobbyism; or mechanisms of social glamorization. To address these research gaps will require a considerable research effort, without which the implementation of significant sustainable transport policies is however unlikely.

\section{References}

AAA (2013). AAA Fact Sheet. http://newsroom.aaa.com/about-aaa/aaa-fact-sheet-2/ Accessed 14.01.2013.

ADAC (2013). Mitgliederwachstum im Minutentakt - das ADAC Geschäftsjahr 2010. Available: http://www.adac.de/wir-ueberuns/daten_fakten/jahresabschlussbericht/default.aspx?ComponentId=82112\&SourcePa geId=73854 Accessed 14.01.2013.

Adey, P., Budd, L. and Hubbard, P. (2007). Flying lessons: exploring the social and cultural geographies of global air travel, Progress in Human Geography 31(6): 773-91.

Adey, P. (2010). 'Ten thousand lads with shining eyes are dreaming and their dreams are wings': affect, airmindedness and the birth of the aerial subject. Cultural Geographies, 18(1), 63-89.

Airbus (2012). Global Market Forecast 2012-2031. http://www.airbus.com/company/market/forecast/ Accessed 23.11.2012 
Åkerman, J. (2012). Climate impact of international travel by Swedish residents. Journal of Transport Geography 25: 87-93.

Anable, J. (2005). Complacent car addicts' or 'aspiring environmentalists? Identifying travel behaviour segments using attitude theory. Transport Policy, 12, 65-78.

Anable, J., Brand, C., Tran, M. and Eyre, N. (2012). Modeling transport energy demand: a socio-technical approach. Energy Policy 41, 125-138.

ARD (2013). Der ADAC-Check. Available: http://www.daserste.de/information/reportagedokumentation/markencheck/sendungen/adac-check-100.html Accessed 16.1.14.

Ares, E. (2012) EU ETS and Aviation, Standard Note SN.SC/5533. 2012. London: House of Commons Library.

Asensio, J., Gómez-Lobo, A. and Matas, A. (2014). How effective are policies to reduce gasoline consumption? Evaluating a set of measures in Spain. Energy Economics 42: 34-42.

Bach, S., Corneo, G., and Steiner, V. (2009). From bottom to top: the entire income distribution in Germany, 1992-2003. Review of Income and Wealth 55(2): 303-330.

Banister, D., (2008). The sustainable mobility paradigm. Transport Policy 15 (1), $73-80$.

Banister, D., (2011). Cities, mobility and climate change. Journal of Transport Geography 19 (6), 1538-1546.

Banister, D. and Hickman, R. (2013), Transport futures: Thinking the unthinkable. Transport Policy 29: 283-293.

Banister, D., Schwanen, T. and Anable, J. (2012). Introduction to the special section on theoretical perspectives on climate change mitigation in transport. Journal of Transport Geography 24: 467-470.

Barr, S. Shaw, G. Coles, T. and Prillwitz, J. (2010). "A holiday is a holiday”: practicing sustainability, home and away. Journal of Transport Geography 18: 474-481.

Bauman, Z. (2007). Liquid Modernity. Oxford, Blackwell Publishers Ltd.

BBC (2013a). Germany delays EU limit on CO2 emissions from cars. Available: http://www.bbc.co.uk/news/world-europe-24532284. Accessed 16.1.2014.

BBC (2013b). Airports Commission reveals expansion shortlist. Available: http://www.bbc.co.uk/news/business-25402007. Accessed 16.1.14.

Beck, U. and Beck-Gernsheim (2014). Distant Love. Polity Press: Cambridge.

Beck, U. (2007). Weltrisikogesellschaft. Frankfurt am Main, Suhrkamp. 
Becker, U. J., Becker, T. and Gerlach, J. (2012). Externe Autokosten in der EU-27. Überblick über existierende Studien. Technische Universität Dresden, Lehrstuhl für Verkehrsökologie.

Boeing. 2012. Current Market Outlook 2012-2031. Available: www.boeing.com/commercial/cmo Accessed 23.10.2012.

Börjesson, M., Eliasson, J., Hugosson, M.B., and Brundell-Freij, K. (2012). The Stockholm congestion charges -5 years on. Effects, acceptability and lessons learnt. Transport Policy 20: 1-12.

Brand, C. and Preston, J. M. (2010). `60-20 emission' - The unequal distribution of greenhouse gas emissions from personal, non-business travel in the UK. Transport Policy, 17: 9-19.

Bright, M. and Matsuura, K. (2009). 1001 Natural Wonders You Must See Before You Die: UNESCO Edition. Quintessence, London.

Brulle, R.J. (2013). Institutionalizing delay: foundation funding and the creation of U.S. climate change counter-movement organizations. Climatic Change, doi: $10.1007 / \mathrm{s} 10584-013-1018-7$

BUND 2007. Forsa-Umfrage: Mehrheit der Bundesbürger will mehr Engagement der Regierung beim Klimaschutz, ein Tempolimit und keine neuen Kohlekraftwerke. Available: http://www.bund.net/nc/presse/pressemitteilungen/detail/zurueck/suche-inpressemitteilungen/artikel/forsa-umfrage-mehrheit-der-bundesbuerger-will-mehrengagement-der-regierung-beim-klimaschutz-ein-t/forsa/ Accessed 15.01.2013.

Bundesamt fuer Strassen 2012. Mehr Verkehrssicherheit dank Via sicura. Available http://www.astra.admin.ch/themen/verkehrssicherheit/00236/index.html?lang=de Accessed 30.01.2013.

Bundeswahlleiter (2013). Sitze der Parteien im 14. Deutschen Bundestag 1998. Available http://www.bundeswahlleiter.de/de/bundestagswahlen/fruehere bundestagswahlen/bt w1998.html Accessed 15 May 2014.

Bureau of Transportation Statistics 2008 Various documents, online, available: http://www.transtats.bts.gov/ Accessed 01.08.2008

Carlsson-Kanyama, A. and Lindén, A.-L. (1999). Travel patterns and environmental effects now and in the future: implications of differences in energy consumption among socio-economic groups. Ecological Economics 30: 405-417.

Casey, M.E. (2010). Low cost air travel: Welcome aboard? Tourist Studies, 10(2), 175- 
191.

Chapman, L., (2007). Transport and climate change: a review. Journal of Transport Geography 15 (5), 354-367.

Chèze, B., Chevallier, J. and Gastineau, P. (2013). Will technological progress be sufficient to stabilize CO2 emissions from air transport in the mid-term? Transportation Research Part D: 91-96.

City of Copenhagen 2009. Economic evaluation of cycle projects - methodology and unit prices. Available from:

http://subsite.kk.dk/sitecore/content/Subsites/CityOfCopenhagen/SubsiteFrontpage/Li vingInCopenhagen/CityAndTraffic/CityOfCyclists/CycleStatistics/socioeconomicbene fits.aspx. Accessed 20.12.2012.

City of Copenhagen 2011. Fra God til Verdens Bedste. Københavns cykelstrategi 2011-2025. [Good, Better, Best. The City of Copenhagen's bicycle strategy 2011-2025]. Available from: http://www.kk.dk/da/Om-kommunen/Indsatsomraader-ogpolitikker/Publikationer.aspx?mode=detalje\&id=818 Accessed 20.12.2012.

City of Copenhagen 2012. Københavns Miljøregnskab 2011 [Copenhagen's Environmental Balance Sheet] Available: http://www.kk.dk/da/Om-kommunen/Indsatsomraader-ogpolitikker/Publikationer.aspx ?mode=detalje\&id=872 Accessed 20.12.2012.

CNN 2010. The fabulous lives of air miles millionaires. Available: http://edition.cnn.com/2010/BUSINESS/01/21/frequent.flier.millionaires/index.html Accessed 15.01.2013.

Cohen, S.A. and Higham, J.E.S. (2011). Eyes wide shut? UK consumer perceptions on aviation climate impacts and travel decisions to New Zealand. Current Issues in Tourism, 14, 323-335.

Cohen, S.A., Higham, J.E.S., \& Cavaliere, C.T. (2011). Binge flying: Behavioural addiction and climate change. Annals of Tourism Research, 38, 1070-1089.

Cohen, S.A., Higham, J.E.S. \& Reis, A.C. (2013). Sociological barriers to developing sustainable discretionary air travel behaviour. Journal of Sustainable Tourism, 21(7), 982-998.

Copenhagen Economics 2009. Company Car Taxation. Available: http://ec.europa.eu/taxation_customs/resources/documents/taxation/gen_info/economi c_analysis/tax_papers/taxation_paper_22_en.pdf Accessed: 23.01.2013.

Cramer, M. 2013. Wiegen mit zweierlei Mass. Geschäftsmodell von Ryanair. Available 
http://www.michael-cramer.eu/presse/pressemitteilungen/single-view/article/wiegenmit-zweierlei-m/ Accessed: 17.01.2013.

Credit Suisse (2013). Global Wealth Databook 2013. Available https://publications.creditsuisse.com/tasks/render/file/?fileID=BCDB1364-A105-0560-1332EC9100FF5C83 Accessed 12.05.2014.

Daly, H.E., and Ó Gallachóir, B.P. (2011) Future energy and emissions policy scenarios in Ireland for private car transport. Energy Policy 39 (2011) 7815-7824

Department of Transport (2007). Air Passenger Demand and CO2 Forecasts. London: Department of Transport.

D’Haultfœuille, X., Durrmeyer, I. and Février, P. (2011). Le coût du bonus/malus écologique: Que pouvait-on prédire? Revue économique 62(3), 491-499.

Doganis, R. (2006). The Airline Business. 2nd edition. London: Routledge.

Douglas, M. (1966). Purity and Danger. An Analysis of the Concepts of Pollution and Taboo. Routledge: London.

Douglas, M.J., Watkins, S.J., Gorman, D.R. and Higgins, M. (2011). Are cars the new tobacco? Journal of Public Health 33(2): 160-169.

Dubois, G., Ceron, J.-P., Peeters, P., and Gössling, S. (2011). The future tourism mobility of the world population: Emission growth versus climate policy. Transportation Research Part A 45: 1031-1042.

Dray, L.M., Schäfer, A., and Ben-Akiva, M.E. (2012). Technology Limits for Reducing EU Transport Sector $\mathrm{CO}_{2}$ Emissions. Environmental Science \& Technology 46: 47344741 .

EC (2006) European Commission. Impact Assessment, COM (2006) 818 final, 20 December 2006.

EC (2011) COMMISSION STAFF WORKING DOCUMENT. Accompanying the White paper. Roadmap to a Single European Transport Area - Towards a competitive and resource efficient transport system, COM (2011) 144 final, Brussels, European Commission.

EC (2012) EU Transport in figures. Statistical Pocketbook 2012. Available: http://ec.europa.eu/transport/facts-fundings/statistics/doc/2012/pocketbook2012.pdf Accessed: 05.02.2013 
EC (2013) Commission submits formal proposal to defer EU ETS international aviation compliance by one year. Available:

http://ec.europa.eu/clima/news/articles/news_2012112001_en.htm Accessed: 11.02.2013

EC (2014). Reducing emissions from aviation. Available: http://ec.europa.eu/clima/policies/transport/aviation/index_en.htm Accessed 12.05 .2014

Edensor, T. (2004). Automobility and national identity: representation, geography and driving practice. Theory, Culture and Society 21(4-5), 101-120.

Eurobarometer. (2011). Attitudes of European citizens towards the environment. Retrieved 28.02.2011, from http://ec.europa.eu/environment/pdf/ebs_365_en.pdf

Friman, M., Larhult, L and Gärling, T. (2012). An analysis of soft transport policy measures implemented in Sweden to reduce private car use. Transportation, 40(1), 109-129.

Frändberg, L. (2008). Paths in transnational time-space: representing mobility biographies of young Swedes. Geografiska Annaler B 90 (1): 17-28.

Gössling, S. (2013). Advancing a clinical transport psychology. Transportation Research Part F: Traffic Psychology and Behaviour, 19, 11-21.

Gössling, S., Bredberg, M., Randow, A., Svensson, P. and Swedlin, E. (2006). Tourist perceptions of climate change: a study of international tourists in Zanzibar. Current Issues in Tourism 9(4-5): 419-435.

Gössling, S., Ceron, J.-P., Dubois, G., and Hall, C.M. (2009). Hypermobile travellers. In Gössling, S. and Upham, P. (eds) Climate Change and Aviation. Earthscan, pp. 131149.

Gössling, S. and Nilsson, J.H. (2010). Frequent Flyer Programmes and the Reproduction of Mobility. Environment and Planning A, 42: 241-252.

Gössling, S. and Peeters, P. (2007). "It does not harm the environment!” - An analysis of discourses on tourism, air travel and the environment. Journal of Sustainable Tourism, 15(4): $402-417$.

Gössling, S., Peeters, P and Scott D. (2008). Consequences of climate policy for international tourist arrivals in developing countries. Third World Quarterly 29: 873-901.

Gössling, S., Choi, A. and Ritchie, B. (2014). The economics of bicycling: CBA for sustainable transportation in Copenhagen. Ecological Economics, submitted. 
Hall, C.M. (2013). Tourism and Social Marketing, London: Routledge.

Hares, A., Dickinson, J. and Wilkes, K. (2010). Climate change and the air travel decisions of UK tourists, Journal of Transport Geography, 18(3), 466-473.

Hels, T., Lyckegaard, A.and Pilegaard, N. (2011). Evaluering af trafiksikkerhedstiltag - en vejledning. DTU Transport Available:

http://www.transport.dtu.dk/upload/institutter/dtu\%20transport/notater/skabelon\%20fo r\%20evalueringer\%20af\%20trafiksikkerhedstiltag.pdf Accessed 24.01.2013.

Hibbert, J.F., Dickinson, J.E., Gössling, S. and Curtin, S. (2013a). Identity and tourism mobility: an exploration of the attitude-behaviour gap. Journal of Sustainable Tourism, 21(7), 999-1016.

Hibbert, J.F., Dickinson, J.E. and Curtin, S. (2013b): Understanding the influence of interpersonal relationships on identity and tourism travel, Anatolia: An International Journal of Tourism and Hospitality Research, 24(1), 30-39.

Hill, N., Brannigan, C., Smokers, R., Schroten, A, van Essen, H., and Skinner, I. (2012). EU Transport GHG: Routes to 2050. Final Report. Available from: http://www.eutransportghg2050.eu/cms/assets/Uploads/Reports/EU-Transport-GHG2050-II-Final-Report-29Jul12.pdf Accessed 18.04.2013.

HM Revenue \& Customs 2013. Air Passenger Duty - introduction. Available http://customs.hmrc.gov.uk/channelsPortalWebApp/channelsPortalWebApp.portal?_n $\mathrm{fpb}=$ true \&_pageLabel=pageExcise_InfoGuides\&id=HMCE_CL_001170\&propertyTy pe=document Accessed 30.01.2013.

Holden, E. and Linnerud, K. (2011). Troublesome leisure travel: The contradictions of three sustainable transport policies. Urban Studies, 48(14): 3087-3106.

IAA 2012: Aussteller IAA PKW 2011. Available: http://www.iaa.de/besucher/datenfakten/daten-fakten/statistiken-aussteller-besucher/ Accessed 14.01.2013.

IATA 2009. A global approach to reducing aviation emissions. 2009. Available at: http://www.iata.org/whatwedo/environment/Pages/index.aspx. (Accessed 27.10-2012.

IATA 2012. 2012 Annual Review. Available from:

http://www.iata.org/about/Documents/annual-review-2012.pdf Accessed: 08.01.2013 .

IATA 2013. Various websites. Available from: www.iata.org Accessed: 05.02.2013.

IEA (2009). Transport, Energy and $\mathrm{CO}_{2}$ : Moving towards sustainability, International Energy Agency: Paris, France. 
IEA (2012). World Energy Outlook 2011. IEA, Paris.

International Air Transport Association (IATA) (2008) 2007 Total Passenger Travel Results, online, available at: http://www.iata.org/ps/publications/2007-results.

International Civil Aviation Organization (ICAO) (2009). A Global Sectoral Approach for Aviation, Working Paper, Montreal: ICAO.

Jotzo F. (2010) Comparing the Copenhagen Emissions Targets, CCEP Working Paper. Canberra: Centre for Climate Economics \& Policy, Crawford School of Economics and Government, The Australian National University; 2010.

Kesselring, S. (2006). Pioneering mobilities: new patterns of movement and motility in a mobile world. Environment and Planning A 38(2): 269-279.

Kroesen, M. (2012) Exploring people's viewpoints on air travel and climate change: understanding inconsistencies. Journal of Sustainable Tourism, 21(2), 271-290.

Kroesen, M. and Handy, S. (2014) The influence of holiday-taking on affect and contentment. Annals of Tourism Research, 45, 89-1010.

Larsen, G.R. and Guiver, J.W. (2013). Understanding tourists' perceptions of distance: a key to reducing the environmental impacts of tourism mobility. Journal of Sustainable Tourism, 21(7), 968-981.

Larsen, J., Urry, J., and Axhausen K.W. (2007). Networks and tourism. Mobile Social Life. Annals of Tourism Research 34(1) 244-262.

Lassen, C. (2006) 'Aeromobility and work', Environment and Planning A 38: 301-12.

Mair, J. (2011). Exploring air travellers' voluntary carbon-offsetting behaviour. Journal of Sustainable Tourism, 19, 215-230.

Mabon, L. (2013). Respect for nature at 200km/h? Exploring the role of lifestyle mobilities in environmental responsibility. In T. Duncan, S.A. Cohen \& M. Thulemarks (Eds.) Lifestyle Mobilities: Intersections of Travel, Leisure and Migration (pp. 239-252) Farnham: Ashgate.

May, A.D. (2013). Urban Transport and Sustainability: The Key Challenges. International Journal of Sustainable Transportation 7(3): 170-185.

Mayor K, Tol RSJ. (2009) Aviation and the environment in the context of the EU-US Open Skies agreement. Journal of Air Transport Management 2009; 15:90-95. 
McKercher, B., Prideaux, B., Cheung, C. and Law, R. (2010). Achieving voluntary reductions in the carbon footprint of tourism and climate change. Journal of Sustainable Tourism 18: $297-318$.

Merriam-Webster (2013). Taboo. Available: http://www.merriamwebster.com/dictionary/taboo Accessed: 05.02.2013.

Mills, S. (2008). The Guardian Weekly 21.03.2008

Murtagh, N., Gatersleben, B., \& Uzzell, D. (2012). Multiple identities and travel mode choice for regular journeys. Transportation Research Part F: Traffic Psychology and Behaviour, 15(5), 514-524.

Netherlands Environmental Assessment Agency (2010). Analyse regeerakkoord. Netherlands Environmental Assessment Agency (PBL): The Hague, Netherlands. Available: http://www.pbl.nl/sites/default/files/cms/publicaties/150-10_vrom_met_bijlage.pdf Accessed: 05.02.2013.

Netherlands Environmental Assessment Agency (2011). PBL Note Environmentally harmful subsidies. PBL Publication number 500209002. Available http://www.pbl.nl/sites/default/files/cms/publicaties/PBL_2011_Environmentally\%20 Harmful\%20Subsidies_500209002.pdf Accessed: 05.02.2013.

News.at http://www.news.at/articles/0503/10/103091/news-grassers-gratis-meilen-minister500-000-bonusmeilen Accessed: 05.02.2013.

Nilsson, M., and Küller, R., (2000). Travel behaviour and environmental concern. Transportation Research Part D 5, 211-234.

Nilsson, J.H. (2009). Low-cost aviation. In Gössling, S. and Upham, P. (eds) Climate Change and Aviation. Earthscan, pp. 113-129.

OECD, UNEP. (2011). Sustainable Tourism Development and Climate Change: Issues and policies. Organization of Economic Cooperation and Development: Paris, France.

Owens, B., Lee, DS.and Lim, L. (2010). Flying into the future: aviation emissions scenarios to 2050. Environmental Science Technology 44: 2255-2260. DOI: 10.1021/es902530z.

Peeters, P., Gössling, S. and Becken, S. (2007a). Innovation towards tourism sustainability: climate change and aviation. International Journal of Innovation and Sustainable Development, 1(3): 184-200.

Peeters, P., Szimba, E., and Duijnisveld, M. (2007b). Major environmental impacts of European tourist transport. Journal of Transport Geography, 15, 83-93. 
Pentelow, L. and Scott, D. (2010) The implications of climate change mitigation policy: volatility for tourism arrivals to the Caribbean. Tourism and Hospitality Planning and Development, 2010; 7(3):301-315.

Pentelow, L. and Scott, D. (2011) Aviation's inclusion in international climate policy regimes: Implications for the Caribbean tourism industry. Journal of Air Transport Management 17:199-205.

Radcliffe-Brown, A.R. (1939). Taboo. Cambridge University Press: Cambridge.

Randles, S. and Mander, S. (2009) Aviation, consumption and the climate change debate: 'Are you going to tell me off for flying?'. Technology Analysis \& Strategic Management, 21(1): 93-113.

Rietveld, P. and Stough, R. (eds) (2005). Barriers to Sustainable Transport. Institutions, Regulation and Sustainability. Spon Press: Abingdon, UK.

Rijkswaterstaat (2011). Onderzoek invoering verhoging maximumsnelheid naar $130 \mathrm{~km} / \mathrm{h}$. Rijkswaterstaat, www.rijkswaterstaat.nl.

Scandinavian Airlines (SAS) (2008). Can I fly with a clear environmental conscience? Available:

http://www.flysas.com/upload/International/SKI/travel_info/SAS_Environment_folder .pdf Accessed 24.01.2013.

Schäfer, A., Heywood, J.B., Jacoby, H.D., and Waitz, I.A. (2009). Transportation in a climate-constrained world. Cambridge, Massachusetts: MIT Press.

Schwanen, T. and Lucas, K. (2011). Understanding Auto Motives. In Lucas, K., Blumenberg, E. and Weinberger, R. (eds) Auto Motives. Understanding Car Use Behaviours. Bingley, Emerald.

Schwanen, T., Banister, D., and Anable, J. (2011). Scientific research about climate change mitigation in transport: a critical review. Transportation Research Part A, 45: $993-$ 1006.

Schwanen, T., Banister, D., and Anable, J. (2012). Rethinking habits and their role in behaviour change: the case of low-carbon mobility. Journal of Transport Geography, $24,522-532$.

Scott, D, Gössling, S., and Hall, C.M. (2012). Tourism and climate change: Impacts, adaptation and mitigation. London: Routledge.

Scott, D, Peeters, P., and Gössling, S. (2010). Can tourism deliver its 'aspirational' emission reduction targets? Journal of Sustainable Tourism, 18, 393-408. 
Sheller, M. (2004). Automotive emotions: Feeling the car. Theory, Culture and Society 21(4/5), 221-245.

Sheller, M. and Urry, J. (2006). The new mobilities paradigm. Environment and Planning A 28(2): 207-226.

Spiegel 2012. Lufthansa-Programm Miles \& More: Vielfliegern droht Niederlage im Meilenstreit. Available: http://www.spiegel.de/reise/aktuell/bonusmeilen-vielfliegerdroht-streit-mit-lufthansa-zu-verlieren-a-868206.html Accessed 15.01.2013.

Statistisches Bundesamt 2012. Alleinlebende in Deutschland. Available https://www.destatis.de/DE/PresseService/Presse/Pressekonferenzen/2012/Alleinleben de/begleitmaterial_PDF.pdf?_blob=publicationFile Accessed 25.01.2013.

Sterner, T. (2007). Fuel taxes: an important instrument for climate policy. Energy Policy 35: 3194-3202.

Stough, R.R. and Rietveld, P. (1997). Institutional issues in transport systems. Journal of Transport Geography 5(3): 207-214.

Stratton, R.W., Min Wong, Hsin. and Hileman, J.I. (2010) Life cycle greenhouse gas emissions from alternative jet fuels. Partnership for AiR Transportation Noice and Emissions Reduction. Massachusetts Institute of Technology, Cambridge, Massachusetts.

Süddeutsche Zeitung 2010. Deutsche für Tempolimit auf Autobahnen. Available: http://www.sueddeutsche.de/auto/umfrage-deutsche-fuer-tempolimit-auf-autobahnen1.623163 Accessed 15.01.2013.

Süddeutsche Zeitung 2011. Dienstfahrräder für Piraten abgelehnt. Available http://www.sueddeutsche.de/politik/berliner-abgeordnetenhaus-dienst-fahrraeder-fuerpiraten-abgelehnt-1.1217860 Accessed 23.01.2013.

Sustainable Consumption Roundtable (2006). Shifting opinions and changing behaviours. A Consumer Forum report by Opinion Leader Research, May 2006. London: Sustainable Development Roundtable.

T\&E 2012. Review of existing legislation on VAT reduced rates. Available http://www.transportenvironment.org/sites/te/files/publications/VAT\%20Reduced\%20 Rates\%20Consultation_FINAL.pdf Accessed 16.01.2013.

Tetlock, P.E. (2003). Thinking the unthinkable: sacred values and taboo cognitions. Trends in Cognitive Sciences 7(7): 320-324. 
Tetlock, P.E., Kristel, O.V., Elson, S.B., Green, M.C. and Lerner, J.S. (2000). The Psychology of the Unthinkable: Taboo Trade-Offs, Forbidden Base Rates, and Heretical Counterfactuals. Journal of Personality and Social Psychology 78(5): 853870.

The Economist (2005) Funny money; frequent-flyer miles. The Economist 377: 8458.

UK Government 2012. Reducing greenhouse gases and other emissions from transport. Available: https://www.gov.uk/government/policies/reducing-greenhouse-gases-andother-emissions-from-transport/supporting-pages/ultra-low-emission-vehicles. Accessed 16.01.2013.

Umweltbundesamt (UBA) 2010. $\mathrm{CO}_{2}$-Emissionsminderung im Verkehr in Deutschland $\left[\mathrm{CO}_{2}\right.$ emission reduction in transport in Germany]. Available http://www.umweltdaten.de/publikationen/fpdf-1/3773.pdf Accessed 24.01.2013.

UNEP (2009). Towards Sustainable Production and Use of Resources: Assessing biofuels. United Nations Environmental Programme: Paris, France.

UNWTO, UNEP, WMO. (2008). Climate Change and Tourism: Responding to Global Challenges. United Nations World Tourism Organization: Madrid, Spain; United Nations Environmental Programme: Paris, France; World Meteorological Organization Geneva, Switzerland.

UNWTO. (2012). UNWTO Tourism Highlights. 2012 Edition. Madrid: United Nations World Tourism Organization.

Urry, J. (2007): Mobilities. Cambridge, Polity Press.

Urry, J. (2011). Social networks, mobile lives and social inequalities. Journal of Transport Geography 21, 24-30.

Urry, J. (2013). Societies beyond oil: Oil dregs and social futures. London, Zed Books.

VCD (2008) Tempolimit für Klimaschutz und Verkehrssicherheit [Speed limit for mitigation and traffic safety]. Available: http://www.vcd.org/fileadmin/user_upload/redakteure_2010/themen/verkehrspolitik/te mpolimit/080325_vcd_position_tempolimit.pdf. Accessed: 05.02.2013.

Vera-Morales, M. and Schäfer, A. (2009). Final Report: Fuel-cycle assessment of alternative aviation fuels. University of Cambridge, Institute for Aviation and the Environment: Cambridge, UK. 
Voigt, K. (2011). Lion who? What record Boeing-Indonesia deal means. CNN International online. Available: http://edition.cnn.com/2011/11/18/business/boeing-lion-airindonesia analysis/index.html?iref=storysearch Accessed: 11.02.2013

Ward's Auto (2011). World Vehicle Population Tops 1 Billion Units. Available: http://wardsauto.com/ar/world_vehicle_population_110815 Accessed: 21.01.2013.

Wen, L.M., Orr, N., Millett, C., and Rissel, C. (2006). Driving to work and overweight and obesity: findings from the 2003 New South Wales Health Survey, Australia. International Journal of Obesity, 30, 782-786.

Wideroe (2013). Experience Norway in one Ticket. Available: http://www.wideroe.no/en/tickets/explore-norway-ticket Accessed: 23.01.2013.

Die Zeit (2013). Der Büttel von Daimler und BMW [Daimler and BMW's beadle]. Available: http://www.zeit.de/mobilitaet/2013-10/autolobby-bundesregierung-co2 Accessed 16.01.2014. 